\title{
Chemical composition, antioxidant and antibacterial activities of essential oils from leaves and flowers of Eugenia klotzschiana Berg (Myrtaceae)
}

\author{
NÁRGELLA S. CARNEIRO ${ }^{1}$, CASSIA C.F. ALVES ${ }^{1}$, JOSÉ M. ALVES ${ }^{1}$, MARIANA B. EGEA ${ }^{1}$, \\ CARLOS H.G. MARTINS ${ }^{2}$, THAYNÁ S. SILVA ${ }^{2}$, LIZANDRA C. BRETANHA ${ }^{3}$, MAIRA P. BALLESTE ${ }^{3}$, \\ GUSTAVO A. MICKE ${ }^{3}$, EDUARDO V. SILVEIRA ${ }^{3}$ and MAYKER L.D. MIRANDA ${ }^{4}$ \\ ${ }^{1}$ Instituto Federal de Ciência e Tecnologia Goiano, Campus Rio Verde, Av. Sul \\ Goiana, s/n, Zona Rural, 75901-970 Rio Verde, GO, Brazil \\ ${ }^{2}$ Núcleo de Pesquisas em Ciências Exatas e Tecnológicas, Universidade de Franca, Av. Dr. \\ Armando Salles Oliveira, 201, Parque Universitário, 14404-600 Franca, SP, Brazil \\ ${ }^{3}$ Universidade Federal de Santa Catarina, Campus Reitor João David Ferreira \\ Lima, s/n, Trindade, 88040-900 Florianópolis, SC, Brazil \\ ${ }^{4}$ Instituto Federal de Educação, Ciência e Tecnologia do Sul de Minas Gerais, Campus Pouso Alegre, \\ Av. Maria da Conceição Santos, 900, Parque Real, 37550-000 Pouso Alegre, MG, Brazil
}

Manuscript received on September 27, 2016; accepted for publication on May 3, 2017

\begin{abstract}
Many essential oils (EOs) of different plant species possess interesting antimicrobial effects on buccal bacteria and antioxidant properties. Eugenia klotzschiana Berg (pêra-do-cerrado, in Portuguese) is a species of Myrtaceae with restricted distribution in the Cerrado. The essential oils were extracted through the hydrodistillation technique using a modified Clevenger apparatus ( 2 hours) and chemically characterized by GC-MS. The major compounds were $\alpha$-copaene $(10.6 \%)$ found in oil from leaves in natura, $\beta$-bisabolene $(17.4 \%)$ in the essential oil from dry leaves and $\alpha-(E)$-bergamotene $(29.9 \%)$ in oil from flowers. The antioxidant activity of essential oils showed similarities in both methods under analysis (DPPH and $\mathrm{ABTS}^{+}$) and the results suggested moderate to high antioxidant activity. The antibacterial activity was evaluated by determining minimum inhibitory concentrations (MICs), using the microdilution method. MIC values below $400 \mu \mathrm{g} / \mathrm{mL}$ were obtained against Streptococcus salivarius $(200 \mu \mathrm{g} / \mathrm{mL})$, S. mutans (50 $\mu \mathrm{g} / \mathrm{mL})$, S. mitis $(200 \mu \mathrm{g} / \mathrm{mL})$ and Prevotella nigrescens $(50 \mu \mathrm{g} / \mathrm{mL})$. This is the first report of the chemical composition and antibacterial and antioxidant activities of the essential oils of E. klotzschiana. These results suggest that E. klotzschiana, a Brazilian plant, provide initial evidence of a new and alternative source of substances with medicinal interest.
\end{abstract}

Key words: Antioxidant activity, antibacterial activity, Brazilian pear, drying, Eugenia klotzschiana, sesquiterpenes.

Correspondence to: Mayker Lazaro Dantas Miranda

E-mail: mayker.miranda@ifsuldeminas.edu.br 


\section{INTRODUCTION}

Essential oils from different plant sources carry out several biological activities, such as antibacterial, anticancer, anti-inflammatory, antimutagenic, antifungal, antioxidant and antiprotozoal ones. As a result, the vast arsenal of bioactive compounds found in essential oils has increasingly attracted researchers' intense attention in the last years (Raut and Karuppayil 2014).

The species Eugenia klotzschiana Berg (pêrado-cerrado, in Portuguese), which is a species of Myrtaceae with restricted distribution in the Cerrado, yields fruits with nutritional potential that can be extracted from nature as raw material for the production of jams, jellies and juices. However, this rare species has been little studied (Oliveira et al. 1999). E. klotzschiana is a species found in tropical regions and that adapts well to drained and permeable soils, such as the ones in Goiás, the Federal District, Mato Grosso, Mato Grosso do Sul, Minas Gerais and southwestern Bahia (Oliveira et al. 1999, Takao et al. 2015). Recent studies have shown that this species can also be found in Bolivia (Villarroel and Proença 2013).

The Myrtaceae family, one of the most important of Brazilian flora, has representatives of great medicinal interest. This family presents pantropical and subtropical distribution, has about 130 genera and 4000 species. In Brazil there are 23 genera and approximately 1000 species (Paula et al. 2010). Species of the Myrtaceae family, such as E. klotzschiana, have stood out as rich sources of essential oils with important economic and health benefits (D'Angelis and Negrelle 2014).

Aromatic plants, mainly their essential oils, have been widely evaluated regarding their antioxidant and antimicrobial activities since they have been used in food and drink industries as natural antioxidants (Amiri 2012, Hellali et al. 2016). Their attributes are the result of the capacity some of their components, mainly phenols, have to interrupt or mitigate oxidation. Well-known methods, such as DPPH and $\mathrm{ABTS}^{+}$, may be used for evaluating the antioxidant activity (Almeida et al. 2011).

The procedure, which yields the essential oil from the raw material, limits the phenolic content in the final matrix because many compounds are non-volatile. However, there are phenol-free essential oils which have antioxidant behavior due to the chemical structure of their constituents (Amorati et al. 2013). Consequently, there has been more interest in the use of natural substances as antioxidants not only because of toxicological worries related to the use of synthetic ones for long periods but also because of awareness-raising processes concerning the consumption of natural food (Singh et al. 2012).

Regarding antibacterial activity, several papers have reported the antimicrobial potential of essential oils (EOs) from plants against oral pathogens over the last decade (Sousa et al. 2015). EOs consist of mixtures of a variety of lipid-soluble and volatile compounds, such as monoterpenes, sesquiterpenes and phenylpropanoids, which can easily diffuse across cell membranes, a major advantage with regard to interactions with intracellular targets. Additionally, synergistic interactions among the components of EOs may happen and benefit their activities (Raut and Karuppayil 2014).

This study describes, for the first time, the chemical composition and the antioxidant and antibacterial activities in vitro of essential oils from leaves of E. klotzschiana (Myrtaceae), a species found in the Brazilian Cerrado in southwestern Goiás.

\section{MATERIALS AND METHODS}

COLLECTION AND IDENTIFICATION OF THE PLANT MATERIAL

Leaves and flowers of E. klotzschiana were collected in an area of Cerrado vegetation, located 
in Portelândia (Goiás) (17 $23^{\prime} \mathrm{S}$ and $\left.52^{\circ} 38^{\prime} \mathrm{W}\right)$, in March 2014. The plant material was identified by the botanist Erika Amaral, Ph.D. Samples were stored at the Herbário Germano Guarim Neto, which belongs to the Universidade Federal de Goiás (no. HJ 7413 - leaves and no. HJ 7414 - flowers).

\section{DRYING PROCESS OF THE PLANT MATERIAL}

In order to evaluate the influence of drying on the content and composition of essential oils from leaves of E. klotzschiana Berg, they were submitted to three treatments: $i$ ) leaves in natura; ii) natural drying at room temperature; and iii) kiln drying by forced air circulation at $40{ }^{\circ} \mathrm{C} \pm 2{ }^{\circ} \mathrm{C}$.

In the natural drying process, $1000 \mathrm{~g}$ leaves in natura were placed in thin layers at room temperature, with no incident solar radiation, at the Laboratório de Química de Produtos Naturais, which belongs to the Instituto Federal Goiano, Campus Rio Verde. Gravimetric monitoring of reduction in water content was carried out throughout the process of leaf drying with the help of a $0.01 \mathrm{~g}$ resolution scale. Drying lasted 72 hours, up to 50 $\%$ reduction in the initial mass weight. Afterwards, leaves were submitted to hydrodistillation to have their essential oil extracted.

In kiln drying by forced air circulation, 1000 $\mathrm{g}$ leaves were stored in Kraft paper bags, identified and placed in the kiln at $40{ }^{\circ} \mathrm{C} \pm 2{ }^{\circ} \mathrm{C}$ for 48 hours. The end of drying was achieved when there was $50 \%$ reduction in the initial mass weight. Flowers were collected and immediately submitted to the extraction of their essential oil, i.e., no drying process was carried out.

\section{ISOLATION OF ESSENTIAL OILS}

Essential oils were extracted from leaves (100 g) and flowers (100 g) of E. klotzschiana by a modified Clevenger-type apparatus and 2-hour hydrodistillation. The oil was separated and dried over anhydrous sodium sulfate, stored in hermetically sealed glass containers and kept under refrigeration at $5{ }^{\circ} \mathrm{C}$ until the analysis and antibacterial and antioxidant assays. Total oil yield was expressed as a percentage value $(\mathrm{g} / 100 \mathrm{~g}$ of fresh plant material). All experiments were carried out in triplicate.

GC-MS ANALYSIS

GC-MS analysis was done on a Agilent Technologies 7820A GC and MSD 5975 using DB-5MS column (30 $\mathrm{m} \times 0.25 \mathrm{~mm}, 0.25 \mathrm{~mm}$ in thickness). The carrier gas was $\mathrm{He}$ with pressure of $57.4 \mathrm{kPa}$ and flow rate of $1.00 \mathrm{~mL} / \mathrm{min}$. The split ratio was $1 / 30$, the injector temperature was $250^{\circ} \mathrm{C}$ and the injected volume was $1 \mu \mathrm{L}$. Temperature programming was the following : $60-240{ }^{\circ} \mathrm{C}$ increasing in $3{ }^{\circ} \mathrm{C} /$ min. MS were recorded on electron ionization (EI) mode, with ionization energy of $70 \mathrm{eV}$ (scan time: 2 scans/s). The identification of constituents was carried out based on the retention indices (calculated using from $\mathrm{C}_{9}$ to $\mathrm{C}_{22}$ alkanes) and by comparing the mass spectra with a computer databank (Wiley 7 and Nist 62) and with reference to published data (Adams 2007).

\section{ASSESSMENT OF THE ANTIOXIDANT ACTIVITY}

Quantification by the DPPH method was carried out in agreement with Rufino et al. (2007a), based on the capture of the free radical 2,2-diphenyl-1picrylhydrazyl (DPPH) by antioxidant substances. Samples of essential oils of leaves and flowers $(0.1 \mathrm{~mL})$ at different concentrations $(2000,4000$, 6000,8000 and $10000 \mathrm{mg} / \mathrm{L}$ ) were added to $3.9 \mathrm{~mL}$ DPPH solution and kept for 60 minutes in the dark. Absorbance was read at $515 \mathrm{~nm}$ wave length by a UV-Vis digital spectrophotometer Bel Engineering model UV-M51 in quadruple. A DPPH standard curve was constructed by using solutions whose concentrations ranged from 10 to $60 \mu \mathrm{M}$. The DPPH calibration equation obtained the following correlation coefficient: $\mathrm{R}^{2}=0.99$. Results were 
expressed as $\mathrm{EC}_{50} \mu \mathrm{g} / \mathrm{mL}$ (amount of sample which was needed to decrease the initial concentration of the radical DPPH in $50 \%$ ), as g oil/g DPPH and as inhibition percentage of every concentration, as follows:

$\% \mathrm{AA}=\{($ Abs control - Abs sample $) \times 100\} / \mathrm{Abs}$ control

The antioxidant activity assay was carried out by the Trolox equivalent antioxidant capacity (TEAC) method and the radical ABTS ${ }^{+}(2,2$-azinobis-3-ethylbenzoline-6-sulfonic acid) was captured in agreement with the procedure described by Rufino et al. (2007b). Preparation of the radical ABTS'+ was based on the reaction between $5 \mathrm{~mL} \mathrm{ABTS}^{+}$ aqueous solution $(7 \mathrm{mM})$ and $88 \mu \mathrm{L}$ potassium persulfate solution (140 mM), which was left for 16 hours in the dark. Afterwards, the mixture was diluted with ethanol to reach absorbance of 0.70 $\mathrm{nm} \pm 0.05$ at $734 \mathrm{~nm}$. An aliquot of $30 \mu \mathrm{L}$ of every dilution of essential oils from leaves and flowers (from 2000 to $10000 \mathrm{mg} / \mathrm{L}$ ) was added to $3 \mathrm{~mL}$ of the radical $\mathrm{ABTS}^{+}$in test tubes and left for 6 minutes in the dark. Absorbance was read at $734 \mathrm{~nm}$ by a spectrophotometer whose blank was ethanol. A Trolox curve at different concentrations (from 100 to $2000 \mu \mathrm{M}$ ) was prepared and used as the standard. The $\mathrm{ABTS}^{+}$calibration curve obtained the following correlation coefficient: $\mathrm{R}^{2}=0.99$. Results were expressed as Trolox micromole per gram of oil ( $\mu \mathrm{M}$ trolox/g).

\section{STATISTICAL ANALYSIS}

Results of antioxidant analyses were submitted to the analysis of variance (ANOVA) whereas the Tukey's test $(p<0.05)$ was applied so that the means could be compared. Statistical calculations were carried out by Excel (version 2007) and Assistat.

\section{MICROORGANISMS UNDER INVESTIGATION}

Bacteria were acquired from the American Type Culture Collection (ATCC) and kept in the culture collection of the Laboratory of Research on Applied Microbiology (LaPeMA), which belongs to the Universidade de Franca, located in Franca, São Paulo, Brazil, at $-80{ }^{\circ} \mathrm{C}$. The following microorganisms were used: Streptococcus salivarius (ATCC 25975), Streptococcus mutans (ATCC 25175), Streptococcus mitis (ATCC 49452), Streptococcus sanguinis (ATCC 10556), Streptococcus sobrinus (ATCC 33478) and Prevotella nigrescens (ATCC 33563).

\section{ANTIMICROBIAL ASSAYS}

MIC values of essential oils were determined by the broth microdilution method in 96-well microplates, in agreement with the methodology described by CLSI (2006). Samples were dissolved in $125 \mu \mathrm{L}$ tryptic soy broth (TSB) to yield concentrations between 50 and $400 \mu \mathrm{g} / \mathrm{mL}$ of the compounds under investigation. The inoculum was adjusted to $625 \mathrm{~nm}$ for every microorganism by the spectrophotometer to obtain cell concentration of $5 \times 10^{5}$ colony-forming units (CFU/mL) (CLSI 2006). Chlorhexidine digluconate (Sigma-Aldrich), at concentrations which ranged from 0.115 to 59.0 $\mu \mathrm{g} / \mathrm{mL}$, was employed as the positive control. The microplates were incubated at $37{ }^{\circ} \mathrm{C}$ for 24 h; then, $30 \mu \mathrm{L} 0.02 \%$ resazurin (Sigma-Aldrich) aqueous solution was added to every well (Sarker et al. 2007). Resazurin is an oxireduction probe that enables microbial growth to be immediately observed. Blue and red colors represent the absence and the presence of microbial growth, respectively.

\section{RESULTS AND DISCUSSION}

The oil extracted from leaves and flowers of $E$. klotzschiana by hydrodistillation was yellow with high viscosity and strong odor. Essential oils from 
leaves in natura, shade dried leaves, kiln dried leaves and flowers yielded $0.10 \%, 0.17 \%, 0.07 \%$ and $0.09 \%$, respectively.

Thirty five components were identified in every essential oils under study; it represents from 80.8 to $92.9 \%$ of the total composition of volatile essential oils (Table SI - Supplementary Material). Sesquiterpenes predominate in the composition of essential oils from E. klotzschiana. The following main terpenic components were identified: $\alpha$-copaene (10.6\%), $\beta$-bisabolene $(17.4 \%), \alpha$ - $(E)$ bergamotene $(29.9 \%)$ and germacrene-D (13.3\%).

Leaf drying led to modifications in the yield of secondary metabolites due to changes in temperature and the action of biotic and abiotic factors inherent to the development of the plants, as previously described by Oliveira et al. (2016). The essential oil from leaves submitted to shade drying had predominantly sesquiterpenic compounds, mainly $\beta$-bisabolene $(14.0 \%)$ and spathulenol $(10.9 \%)$, likewise the constituents found in the essential oil from leaves in natura.

Kiln drying by forced air circulation at 40 ${ }^{\circ} \mathrm{C}$ interfered in the chemical composition of the essential oil. Out of 35 substances, the ones that had the highest concentrations were: $\beta$-bisabolene (17.4\%), germacrene-D (13.3\%), $\alpha$-caryophyllene $(10.2 \%)$ and $\alpha-(E)$-bergamotene $(10.1 \%)$.

The method of drying medicinal and aromatic plants has been widely used for removing free water from cells and plant tissues, thus, preventing enzymatic degradation processes and keeping the quality of the chemical composition. Drying processes enable plant preservation since physical and chemical characteristics are kept intact. As a result, plants may be stored for a long time. However, the composition of essential oils was observed to undergo changes in post-harvest periods due to spontaneous reactions which happen continuously and alter the composition of essential oils (Oliveira et al. 2011).
The literature mentions that studies of leaves in natura, natural drying and kiln drying at $40{ }^{\circ} \mathrm{C}$ of leaves of long pepper (Piper hispidinervum) showed that the type and time of drying changed the chemical composition of its essential oil, e.g., it increased safrole, its main constituent in the industrial market. Only $78.2 \%$ safrole was found in the oil extracted from the leaves in natura whereas percentages of safrole rose to $90.1 \%$ and $92.6 \%$ when the plant material was dried at room temperature and at $40{ }^{\circ} \mathrm{C}$, respectively. Increases in the concentrations of some substances in the drying process may be explained by the reduction in the excess of humidity, a fact that damages the structures of plant cells and makes the extraction of essential oils easier (Machado et al. 2013).

Regarding the essential oil extracted from flowers of E. klotzschiana, its chemical constituents were observed to be similar to the ones of the essential oil extracted from leaves in natura and dry ones because they also had high content of hydrocarbon sesquiterpenes (64.2\%) (Table SI), mainly $\alpha$ - $(E)$-bergamotene (29.9\%), germacrene-D $(12.1 \%)$ and $\beta$-bisabolene $(10.2 \%)$. Oxygenated monoterpenes, such as geraniol (1.6\%), citronellol $(1.4 \%)$ and phenylpropanoid or eugenol (1.7\%), stand out but these three ones are only found in the essential oil from flowers.

The evaluation of the antioxidant potential of plant species by the DPPH and $\mathrm{ABTS}^{-+}$methods has drawn researchers' attention in their search for bioactive compounds (Almeida et al. 2011). Therefore, in order to measure the antioxidant activity of essential oils from E. klotzschiana, both free radicals DPPH and $\mathrm{ABTS}^{+}$were used. Table II shows the capacity essential oils extracted from leaves (in natura and dry ones) and flowers of $E$. klotzschiana have to capture free radicals.

The essential oil from leaves in natura had high $\mathrm{EC}_{50}=29.77 \mu \mathrm{g} / \mathrm{mL}$, followed by kiln dried leaves $\left(\mathrm{EC}_{50}=7.61 \mu \mathrm{g} / \mathrm{mL}\right)$, shade dried leaves 
TABLE II

Antioxidant activity of essential oils from E. klotzschiana, evaluated by the methods DPPH and ABTS ${ }^{*+}$.

\begin{tabular}{ccccc}
\hline Assays & Leaves in natura & Shade dried leaves & Kiln dried leaves & Flowers \\
\hline Yields $(\%)$ & $0.10 \mathrm{ab}$ & $0.17 \mathrm{a}$ & $0.07 \mathrm{~b}$ & $0.09 \mathrm{~b}$ \\
$\mathrm{DPPH}-\mathrm{EC}_{50} \mu \mathrm{g} / \mathrm{mL}$ & $29.77 \pm 2.25 \mathrm{a}$ & $6.48 \pm 0.69 \mathrm{~b}$ & $7.61 \pm 0.10 \mathrm{~b}$ & $5.70 \pm 0.37 \mathrm{~b}$ \\
$\mathrm{DPPH}-\mathrm{g} / \mathrm{g}$ & $3.25 \pm 0.24 \mathrm{a}$ & $0.71 \pm 0.07 \mathrm{~b}$ & $0.83 \pm 0.01 \mathrm{~b}$ & $0.62 \pm 0.04 \mathrm{~b}$ \\
$\mathrm{ABTS}^{+}-\mu \mathrm{M}$ trolox/g & $57.81 \pm 4.80 \mathrm{c}$ & $143.85 \pm 5.35 \mathrm{a}$ & $106.27 \pm 4.75 \mathrm{~b}$ & $104.61 \pm 4.46 \mathrm{~b}$ \\
\hline
\end{tabular}

Values represent the mean \pm standard deviation of three samples. Means followed by equal letters in the same line do not differ among each other, by the Tukey's test $(\mathrm{p}>0.05)$.

$\left(\mathrm{EC}_{50}=6.48 \mu \mathrm{g} / \mathrm{mL}\right)$ and flowers $\left(\mathrm{EC}_{50}=5.70 \mu \mathrm{g} /\right.$ $\mathrm{mL})$.

In the literature, the most promising antioxidant activity of essential oils has varied from 8.3 to 278 $\mu \mathrm{g} / \mathrm{mL}$, depends on their chemical composition (Tian et al. 2014, Amiri 2012, Pandey et al. 2014). These values were higher than the ones found in essential oils from E. klotzschiana. The antioxidant capacity of the essential oils of E. klotzschiana may be attributed to the presence of the hydrocarbon sesquiterpene germacrene-D, which is a strong antioxidant because of the fact that its chemical structure has an extra cyclic methylene (Victoria et al. 2012).

The literature describes the high antioxidant activity of the essential oil from Indian clove since its majoritarian compound is eugenol, which has been known as a strong antioxidant. This phenylpropanoid was also identified in the essential oil from flowers of E. klotzschiana and has been related to its high antioxidant potential (Teixeira et al. 2013, Affonso et al. 2012, Silvestri et al. 2010).

Results of the measurement of the antioxidant capacity by an ability assay to kidnap the radical ABTS $^{++}$were similar to the ones obtained with $\mathrm{DPPH}$. The essential oil from leaves submitted to natural drying was the one that had the best results by the $\operatorname{ABTS}^{+}(143.85 \mu \mathrm{M}$ trolox/g), followed by artificially dried leaves $(106.27 \mu \mathrm{M}$ trolox/g), the essential oil from flowers $(104.61 \mu \mathrm{M}$ trolox $/ \mathrm{g})$ and dry leaves $(57.81 \mu \mathrm{M}$ trolox $/ \mathrm{g})$. The comparison between ascorbic acid (1593.6 $\mu \mathrm{M}$ trolox/g) and
BHA (1329 $\mu \mathrm{M}$ trolox/g), a synthetic antioxidant used in food, shows that the antioxidant activity of essential oils from E. klotzschiana ranges from moderate to high against the free radical. Damasceno et al. (2011) observed that the more the antioxidant activity increases, the higher the concentration of essential oils. In both methodologies, the essential oil from E. klotzschiana had antioxidant potential but the essential oil from the flowers had higher antioxidant activity.

The evaluation of the antioxidant potential of essential oils from E. klotzschiana showed that there was high correlation between both methods under analysis, the kidnapping activity of the free radical DPPH $\left(\mathrm{R}^{2}=0.99\right)$ and the Trolox equivalent antioxidant capacity $\left(\mathrm{R}^{2}=0.99\right)$. In their study of the species Byrsonima gardneriana, Rolim et al. (2013) stated that these data are evidence of the good antioxidant activity this plant has.

The antioxidant efficiency of essential oils from leaves and flowers of E. klotzschiana has been attributed mainly to its majoritarian components, such as $\beta$-bisabolene, germacrene-D, $\alpha$-caryophyllene and $\alpha$-(E)-bergamotene, even though it may also be caused by the synergic effect of minor components, as well as by the interaction among the compounds (Melo et al. 2011). Therefore, some essential oils stand out as natural antioxidants and, due to technological and nutritional issues, many of them have been studied to replace synthetic antioxidants (Silva et al. 2014). 
The procedure which yields the essential oil from the raw material limits the phenolic content in the final matrix because many compounds are non-volatile. However, there are phenol-free essential oils which have antioxidant behavior due to the chemical structure of their constituents (Amorati et al. 2013). Consequently, there has been more interest in the use of natural substances as antioxidants not only because of toxicological worries related to the use of synthetic ones for long periods but also because of awareness-raising processes concerning the consumption of natural food (Singh et al. 2012).

To perform antibacterial activities, essential oils extracted from leaves in natura, shade-dried leaves and leaves dried at $40{ }^{\circ} \mathrm{C}$ were joined whereas the antibacterial activity of essential oils from flowers was carried out separately. The essential oils were tested against some aerobic/ anaerobic oral microorganisms.

Table III shows that only the anaerobic bacterium $P$. nigrescens and the aerobic bacterium $S$. mutans were significantly inhibited by all essential oils under study, with MIC values ranging from 200 to $50 \mu \mathrm{g} / \mathrm{mL}$. According to Holetz et al. (2002), in case MIC values are below $100 \mu \mathrm{g} / \mathrm{mL}$, the antimicrobial activity can be considered good; from 500 to $100 \mu \mathrm{g} / \mathrm{mL}$, it is moderate; from 1000 to $500 \mu \mathrm{g} / \mathrm{mL}$, it is weak; and above $1000 \mu \mathrm{g} / \mathrm{mL}$, it is inactive. Thus, essential oils from leaves and flowers were the most effective ones against the anaerobic bacterium $P$. nigrescens (MIC $=50 \mu \mathrm{g}$ / $\mathrm{mL}$ ) and against the aerobic bacterium $S$. mutans ( $\mathrm{MIC}=50 \mu \mathrm{g} / \mathrm{mL})$.

This result can be explained by the presence of secondary metabolites, such as sesquiterpenes and monoterpenes, including $\alpha$-copaene, $\alpha-(E)$ bergamotene, $\beta$-bisabolene and eugenol, which have antimicrobial activity against Gram-positive and Gram-negative human pathogens (Lang and Buchbauer 2012, Affonso et al. 2012, Silvestri et al. 2010). Essential oils from leaves and flowers of E. klotzschiana had good antibacterial activity against $P$. nigrescens and $S$. mutans whereas they had moderate activity against $S$. salivarius, $S$. mitis, S. sanguinis and $S$. sobrinus.

In the literature, action mechanisms have been proposed to explain biological activities of essential oils. Both mechanisms are associated with the hydrophobicity of monoterpenes and sesquiterpenes, which are often the main chemicals thereof. The hydrophobicity of terpenoids enables these compounds to permeate cell membranes easily and to cause the death of parasites or microorganisms by affecting their metabolic pathways or organelles (Knobloch et al. 1989).

Therefore, this study led to the conclusion that essential oils from E. klotzschiana showed a complex mixture of monoterpenes and sesquiterpenes, but consisted mainly of sesquiterpenic compounds.

TABLE III

Antimicrobial activity of essential oils from E. klotzschiana against oral bacteria under study.

\begin{tabular}{|c|c|c|c|}
\hline \multirow[t]{2}{*}{ Bacteria } & \multicolumn{3}{|c|}{ Minimum inhibitory concentration (MIC) $-\mu \mathrm{g} / \mathrm{mL}$} \\
\hline & Essential Oil - leaves & Essential Oil - flowers & CHD* \\
\hline Streptococcus salivarius $^{\mathrm{a}}$ & 200 & 200 & 0.922 \\
\hline S. mutans ${ }^{\mathrm{a}}$ & 50 & 50 & 0.922 \\
\hline S. mitis ${ }^{\mathrm{a}}$ & 200 & 200 & 3.688 \\
\hline S. sanguinis ${ }^{\mathrm{a}}$ & 400 & 400 & 0.922 \\
\hline S. sobrinus ${ }^{\mathrm{a}}$ & 400 & 400 & 0.922 \\
\hline Prevotella nigrescens ${ }^{\mathrm{b}}$ & 50 & 50 & 1.844 \\
\hline
\end{tabular}

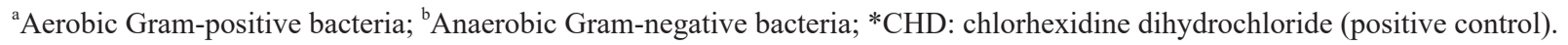


The essential oils from E. klotzschiana under evaluation by the DPPH and $\mathrm{ABTS}^{++}$methods showed antioxidant potential, from moderate to high, a result which agrees with the presence of the compounds germacrene-D and eugenol whose antioxidant activity has been well-known even though the synergic effect of minor constituents was also taken into account.

Finally, essential oils from E. klotzschiana have promising antimicrobial activity against some cariogenic bacteria, such as Streptococcus mutans and Prevotella nigrescens. Moreover, the antimicrobial activity of essential oils from $E$. klotzschiana against oral pathogens makes them potential natural antimicrobial agents.

\section{REFERENCES}

ADAMS RP. 2007. In: Identification of Essential Oil Components by Gas Chromatography/Quadrupole Mass Spectroscopy, $4^{\text {th }}$ ed., Allured Publishing Corporation: Carol Stream, $804 \mathrm{p}$.

AFFONSO RS, RENNÓ MN, SLANA GBCAAND FRANCA TCC. 2012. Aspectos químicos e biológicos do óleo essencial de cravo da índia. Rev Virtual Quim 4: 146-161.

ALMEIDA MMB, SOUSA PHM, ARRIAGA AMC, PRADO GM, MAGALHÃES CEC, MAIA GA AND LEMOS TLG. 2011. Bioactive compounds and antioxidant activity of fresh fruits from Northeastern Brazil. Food Res Int 44: 2155-2159.

AMIRI H. 2012. Essential oils composition and antioxidant properties of three Thymus Species. Evid Based Complement Alternat Med 2012: 728065.

AMORATI R, FOTI MC AND VALGIMIGLI L. 2013. Antioxidant activity of essential oils. J Agric Food Chem 61: 10835-10847.

CLSI - CLINICAL AND LABORATORY STANDARDS INSTITUTE. 2006. Methods for dilution antimicrobial susceptibility tests for bacteria that grow aerobically; Approved Standard Seventh Edition. Clinical and Laboratory Standards Institute document M7-A7.

D’ANGELIS ASR AND NEGRELLE RRB. 2014. Pimenta pseudocaryophyllus (Gomes) Landrum: aspectos botânicos, ecológicos, etnobotânicos e farmacológicos. Rev Bras P1 Med 16: 607-617.

DAMASCENO EIT, SILVA JKR, ANDRADE EHA, SOUSA JC AND MAIA JG. 2011. Antioxidant capacity and larvicidal activity of essential oil and extracts from Lippia grandis. Braz J Pharmacog 21: 78-85.
HELLALI N, MAHAMMED MH, RAMDANE F AND TALLI A. 2016. Antimicrobial and antioxidant activities of Cybopogon schoenanthus (L.) spreng. essential oil, growing in lllizi - Algeria. J Med Plants Res 10: 188-194.

HOLETZ FB, PESSINI GL, SANCHES NR, CORTEZ DAG, NAKAMURA CV AND DIAS FILHO BP. 2002. Screening of some plants used in the Brazilian folk medicine for the treatment of infectious diseases. Mem Inst Oswaldo Cruz 97: 1027-1031.

KNOBLOCH K, PAULI A, IBERL B, WEIGAND H AND WEIS N. 1989. Antibacterial and antifungal properties of essential oil components. J Essent Oil Res 1: 118-119.

LANG G AND BUCHBAUER G. 2012. A review on recent research results (2008-2010) on essential oils as antimicrobials and antifungals. Flavour Frag J 27: 13-39.

MACHADO MP, BERGO CL, DESCHAMPS C, BIZZO HR AND BIASI LA. 2013. Efeito da secagem natural e artificial da biomassa foliar de Piper hispidinervum na composição química do óleo essencial. Semina: Ciências Agrárias 34: 265-270.

MELO NI ET AL. 2011. Schistosomicidal activity of the essential oil of Ageratum conyzoides L. (Asteraceae) against adult Schistosoma mansoni worms. Molecules 16: 762-773.

OLIVEIRA GC, LOPES PSN, NETO FRC, CARVALHO JG AND GAVILANES ML. 1999. Caracterização de plantas de Eugenia klotzschiana Berg (Pêra-do-Cerrado) e do ambiente de sua ocorrência na região fisiográfica dos campos das vertentes em Minas Gerais. R Un Alfenas 5: 9-13.

OLIVEIRA JD, ALVES CCF, MIRANDA MLD, MARTINS CHG, SILVA TS, AMBROSIO MALV, ALVES JM AND SILVA JP. 2016. Rendimento, composição química e atividades antimicrobiana e antioxidante do óleo essencial de folhas de Campomanesia adamantium submetidas a diferentes métodos de secagem. Rev Bras P1 Med 18: 502510.

OLIVEIRA MTR, BERBERT PA, MATOS CRR, MATHIAS L AND MOREIRA RO. 2011. Efeito da temperatura do ar de secagem sobre o teor e a composição química do óleo essencial de Pectis brevipedunculata. Quim Nova 34: 1200-1204.

PANDEY AK, MOHAN M, SINGH P, PALNI UT AND TRIPATHI NN. 2014. Essential composition, antibacterial and antioxidant activity of essential oil of Eupatorium adenophorum Spreng from Easterns Uttar Pradesh, Índia. Food Biosci 7: 80-87.

PAULA JAM, REIS JB, FERREIRA LHM, MENEZES ACS AND PAULA JR. 2010. Gênero Pimenta: aspectos botânicos, composição química e potencial farmacológico. Rev Bras P1 Med 12: 363-379. 
RAUT JS AND KARUPPAYIL SM. 2014. A status review on the medicinal properties of essential oils. Ind Crops Prod 62: 250-264.

ROLIM TL, WANDERLEY FTS, CUNHA EVL, TAVARES JF, OLIVEIRA AMF AND ASSIS TS. 2013. Constituintes químicos e atividade antioxidante de Byrsonima gardneriana (Malpighiaceae). Quim Nova 36: 524-527.

RUFINO MSM, ALVES RE, BRITO ES, MORAIS SM, SAMPAIO CG, PEREZ-GIMENEZ J AND SAURACALIXTO FD. 2007a. Metodologia Científica: Determinação da Atividade Antioxidante Total em Frutas pela Captura do Radical Livre DPPH. Embrapa. Comunicado Técnico 127.

RUFINO MSM, ALVES RE, BRITO ES, MORAIS SM, SAMPAIO CG, PEREZ-GIMENEZ J AND SAURACALIXTO FD. 2007b. Metodologia Científica: Determinação da Atividade Antioxidante Total em Frutas pela Captura do Radical Livre $\mathrm{ABTS}^{+}$. Embrapa. Comunicado Técnico 127.

SARKER SD, NAHAR L AND KUMARASAMY Y. 2007. Microtitre plate-based antibacterial assay incorporating resazurin as an indicator of cell growth, and its application in the in vitro antibacterial screening of phytochemicals. Methods 42: 321-324.

SILVA JA, OLIVEIRA FF, GUEDES ES, BITTENCOURT MAL AND OLIVEIRA RA. 2014. Atividade antioxidante de Piper arboreum, Piper dilatatum e Piper divaricatum. Rev Bras P1 Med 16: 700-706.

SILVESTRI JDF, PAROUL N, CZYEWSKI E, LERIN L, ROTAVA I, CANSIAN RL, MOSSI A, TONIAZZO G, OLIVEIRA D AND TREICHEL H. 2010. Perfil da composição química e atividades antibacteriana e antioxidante do óleo essencial do cravo-da-índia (Eugenia caryophyllata Thunb.). Revista Ceres 57: 589-594.

SINGH HP, KAUR S, NEGI K, KUMARI S, SAINI V, BATISH DR AND KOHLI RK. 2012. Assessment of in vitro antioxidant activity of essential oil of Eucalyptus citriodora (lemon-scented Eucalypt; Myrtaceae) and its major constituents. Food Sci Technol 48: 237-241.

SOUSA RMF ET AL. 2015. Chemical composition, cytotoxic, and antibacterial activity of the essential oil from Eugenia calycina Cambess. leaves against oral bacteria. Ind Crops Prod 65: 71-78.

TAKAO LK, IMATOMI M AND GUALTIERI SCJ. 2015. Antioxidant activity and phenolic content of leaf infusions of Myrtaceae species from Cerrado (Brazilian Savanna). Braz J Biol 75: 948-952.

TEIXEIRA B, MARQUES A, RAMOS C, NENG NR, NOGUEIRA JMF, SARAIVA JAAND NUNES ML. 2013. Chemical composition and antibacterial and antioxidant properties of commercial essential oils. Ind Crops Prod 43: 587-595.

TIAN J, ZENG X, ZHANG S, WANG Y, ZHANG P, LU A AND PENG X. 2014. Regional variation in components and antioxidant and antifungal activities of Perilla frutescens essential oils in China. Ind Crops Prod 59: 6979.

VICTORIA FN, LENARDÃO EJ, SAVEGNAGO L, PERIN G, JACOB RG, ALVES D, SILVA WP, MOTTA AS AND NASCENTE PS. 2012. Essential oil of the leaves of Eugenia uniflora L.: Antioxidant and antimicrobial properties. Food Chem Toxicol 50: 2668-2674.

VILLARROEL D AND PROENÇA C. 2013. A new species and new records of Myrtaceae from the Noel Kempff Mercado National Park region of Bolivia. KewBulletin 68: 261-267.

\section{SUPPLEMENTARY MATERIAL}

Table SI - Chemical composition of essential oils from leaves and flowers of E. klotzschiana. 